The solutions discussed above are obviously quite important, for they will have a great impact on the survival of private institutions. However, several additional new problems have arisen. The government in Korea has always declared its support for the autonomy of private higher education. The government outwardly claims to stand for autonomous decision making by each institution on the adoption of the new division system, creating new professional schools, and so on. But, in practice, no institution has resisted such steps. The private institutions in Korea in their long history have grown so accustomed to accepting government suggestions as a way of protecting themselves from any potential unfair treatment from government. Such a pretense of autonomous uniform policy among private institutions extends throughout all parts of institutional management such as tuition policy, faculty recruitment, admissions, curriculum development, and internal governance. The authentic restructuring of private colleges and universities requires authentic autonomy of higher education institutions.

In July 1998, the government, which has sole authority over the establishment of higher education institutions, permanently shut down two private four-year institutions because of financial deficiency and poor academic management.

Another serious obstacle to restructuring private colleges and universities is the conflict between the private and the public sectors, and among the private institutions themselves. In practice, there are no substantial differences between public and private institutions in Korea, except that the public institutions are wholly government supported but the private ones are not. Institutions in both sectors are set up to be huge comprehensive "department store" institutions. They have not considered their location, the type of students enrolled, their resources, or, more importantly, their missions. It is high time for each institution to reconsider and reaffirm its role and reasons for existing. It is the right path for private institutions to follow to regain the public's trust. In addition, more systematic principles of management and governance should be developed in all corners of institutional life.

\section{Further Privatization in Japanese Higher Education?}

\author{
Akiyoshi Yonezawa \\ Akiyoshi Yonezawa is assistant professor in the Research Institute \\ for Higher Education at Hiroshima University. Address: 1-2-2 \\ Kagamiyama Higashi-Hiroshima 739-8512 Japan. E-mail: \\ <yonezawa@ipc.hiroshima-u.ac.jp>.
}

$\int_{\text {cen }}^{a}$ apan has one of the largest systems of private higher education in the world. More than 65 percent of high school graduates continue their studies; of these, over 70 percent are enrolled in private colleges and universities. Although private institutions receive about 10 percent of their financial resources from public funding, most public expenditure on higher education is allocated to the national and local public universities. The extensive private sector of Japanese higher education is currently threatening the status and viability of the national universities (all of which are public), which have been regarded as essential both for equality of access and the development of scientific research.

Within the national government, there are two different positions on higher education reform. On the one hand, the Ministry of Education has overall responsibility for the operation of the national universities and for the administration of local public and private universities. Therefore, the ministry is attempting to strengthen the quality assessment system for national and local public institutions as well as for private universities, in accordance with its bureaucratic orientation. On the other hand, other parts of government, such as the prime minister's office, respond more to the corporate sector's demands for privatization and deregulation of public services. This office, as well as others, recommends the privatization of national universities on the grounds that this would improve quality by introducing direct market competition. The argument for deregulation also emphasizes the necessity to make information on the quality of universities available for more informed consumer choice.

This controversy within the government complicates the discussion of quality assessment in Japanese higher education. Despite their lack of sophisticated understanding of the character of higher education, the other ministries have continuously pressed for the privatization of the national universities. In contrast, the Ministry of Education has persisted in trying to strengthen its formal assessment system to obtain necessary information for decision making in the al- 
location of public expenditures on higher education.

This controversy began in 1984 when the $\mathrm{Na}$ tional Council on Educational Reform was established as a temporary advisory group on the initiative of then prime minister Yasuhiro Nakasone. The objective at that time was decentralization and the introduction of market competition into what had become a rather stodgy educational system, despite its powerful role in the rapid economic development after the World War II. Following the recommendation of the National Council on Education Reform, the Ministry of Education established the University Council in 1986 as an advisory group of experts including representatives from industry and labor unions. The policies of the University Council basically followed the orientation of the earlier National Council on Educational Reform with regard to deregulation and market competition. At the same time, the University Council recommended the introduction of a "self-monitoring and self-evaluation" system to all institutions-national, local public,and private. The Council argued that continuous selfmonitoring and self-evaluation are essential for revitalizing universities and improving the quality of teaching and research, as well as a way of ensuring that universities fulfill their social responsibilities. This recommendation was put into effect in the June 1991 amendment of the Standards for the Establishment of Universities, which required universities to make efforts to enhance and maintain self-evaluation systems for teaching and research. Under this system, internal and external assessment programs are designed and carried out principally by the individual higher education institutions.

\section{Japan has one of the largest systems of private higher education in the world. More than 65 percent of high school graduates continue their stud- ies; of these, over 70 percent are en- rolled in private colleges and universities.}

The members of the University Council strongly supported this policy of diversified, decentralized systems of assessment of the individual universities as consistent with institutional preferences for academic freedom and autonomy. According to the latest survey conducted by the Research Institute for Higher
Education at Hiroshima University in 1998, 83.7 percent of the nationl, local public, and private universities have already implemented programs of selfmonitoring and self-evaluation, while 15.1 percent of them have introduced some form of external assessment.

In 1998, 83.7 percent of the national and local, public and private universities have already implemented programs of self-monitoring and self-evaluation.

The Japan University Accreditation Association (JUAA) has also had an important influence on these activities. In 1992, the JUAA published guidelines for self-monitoring and self-assessment and introduced a voluntary external evaluation program in 1996. However, most of the leading universities preferred to design their own unique approaches, rather than simply following JUAA guidelines. From the mid1990 s on, the discussion of quality assurance in higher education has been revitalized from another source-the downsizing of Japanese public administration. In response to discussions of recommendations for the restructuring of the national government made by Prime Minister Ryutaro Hashimoto, some education officials have argued strongly for the privatization of all national higher education institutions. For example, in April 1998, an advisory group of economists of education published a report under the auspices of the Economic Planning Agency supporting the privatization plan, and arguing that fair market competition between the national universities and private universities is essential for improving the quality of Japanese higher education. In October 1997, Kiyoshi Mizuno, the chief executive officer of the Administrative Reform Council (the special committee for the restructuring of national government), issued a most striking statement calling for the privatization, as pilot cases, of Tokyo University and Kyoto University, the two most highly regarded national universities. In his view, these universities would likely survive as "administrative corporations," independent of government jurisdiction even under conditions of severe market competition. As to their financial support, there was no clear statement. The Ministry of Education, the Association of National Universities, and the two universities issued 
statements in opposition, calling attention to the important role of the national universities in the field of education and research. In addition, the ministry tried to reply to criticisms of public higher education by developing a more systematic evaluation and quality assurance program. This policy was basically extended to the local public and private sectors as well.

The University Council recently published its own interim report in June 1998. While supporting the role of the national and local public universities, the Council recommended the establishment of a new centralized assessment body that would gather and publish data necessary for fair competition among national, local public, and private universities. This new body would be independent of both the government and the universities.

In its final report of December 1997, the Administrative Reform Council withdrew its recommendation for the immediate privatization of the national universities, while leaving the issue open for continuing discussion. There is no clear evidence that the quality of education and research in the private higher education sector is now equal to or superior to that in the public sector. At the same time, especially as to educational quality, it is quite difficult to identify clear distinctions between national and private institutions.

\section{Japanese higher education has re- lied heavily on the private sector, whose main funding source has been tuition fees.}

Japanese higher education has relied heavily on the private sector, whose main funding source has been tuition fees. The fact that the majority of voters with bachelor's degrees graduated from private institutions might eventually undermine the current advantageous situation of national universities. The introduction of a centralized quality assessment body will be a critical turning point in Japanese government educational policy, especially with respect to the national universities. However, it has yet to be determined whether the new policy will improve the quality of the national universities enough to allow them to compete in an openly competitive market system.

\section{The Society for Research into Higher Education: Advising UNESCO}

\section{Heather Eggins}

Heather Eggins is executive secretary of the Society for Research into Higher Education. Address: Society for Research into Higher Education, 3 Devonshire St., London WIN 2BA, UK.

The work of the Society for Research into Higher Education is fast coming into prominence as the international nongovernmental organization that UNESCO now consults on matters relating to research into higher education. However, it has been making information about higher education issues available to universities and to government alike for well over 30 years.

Its aims are twofold: it exists to stimulate and coordinate research into all aspects of higher education, and aims to improve the quality of higher education through the encouragement of debate and publication on issues of policy, on the organization and management of higher education institutions, on the curriculum, and on teaching and learning methods.

The international nature of the Society is important, and, indeed, distinctive. There are a number of national societies worldwide that address some if not all of the range of issues pursued by the Society-the Association for the Study of Higher Education (ASHE) and the American Association for Higher Education (AAHE), for instancebut there is no other organization specifically founded for an international membership. SRHE's vice-presidents and fellows are drawn from the international community: Martin Trow is a fellow and Elaine El-Khawas a vice-president.

The Society has always had some U.S. corporate members, such as Johns Hopkins University, but the benefits offered in terms of free journals that come as part of the membership and huge discounts off the Society's books (some 35 percent) are not widely known by university libraries and educational research schools in the United States. The Society has a well-established joint imprintSRHE/Open University Press-with some 90 titles in print and publishes three quality journals-Studies in Higher Education, Higher Education Quarterly, and Higher Education Abstracts.

The Society, an independent charity, derives its income from subscriptions, sales of books and journals, conferences, and grants. Its corporate members are institutions of higher education, research institutes, professional, industrial, and governmental bodies: its individual members include professors, researchers, managers, consultants, and 